\title{
Culling reasons and risk factors in Estonian dairy cows
}

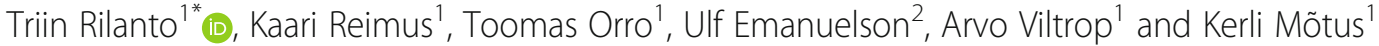

\begin{abstract}
Background: Culling is a major cost for dairy farms but also an essential part in managing herd productivity. This study aimed to identify the culling rates of Estonian dairy cows, identify the farmers' stated reasons and risk factors for culling. This observational study used registry data of all cows from herds with $\geq 20$ cow-years in 2013-2015. Cow lactation-level analyses included data of 86,373 primiparous cows from 409 herds and 177,561 lactations of 109,295 multiparous cows from 410 herds. Weibull proportional hazard regression models were used to identify risk factors for culling due to slaughter or death.

Results: The overall culling rate of Estonian dairy cows was 26.24 (95\% Cl 26.02; 26.46) per 100 cow-years. The most common reasons farmers stated for culling were feet/claw disorders (26.4\%), udder disorders (22.6\%), metabolic and digestive disorders (18.1\%) and fertility problems (12.5\%). Animal-level risk factors for culling were Holstein breed, older parity, lower milk yield breeding value, older age at first calving, longer previous calving interval, having assisted calving, stillbirth and birth of twins/triplets. Lower milk yield, somatic cell count over 200,000 cells/ml and fat/protein ratio over 1.5 at first test-milking after calving were associated with greater culling hazard during the lactation. Cows from larger herds, herds with decreasing size and higher milk yields had a higher culling probability.

Conclusions: This study emphasises the need for improved management of hoof health and prevention of mastitis and metabolic diseases. It is essential to ensure easy calving and good health of cows around calving in order to lower the culling hazard.
\end{abstract}

Keywords: Dairy cow, Estonia, Culling, Slaughter

\section{Background}

Culling is defined as the departure of cows from the herd because of sale, slaughter, salvage, or death [1]. Culling is an important cost for dairy farms [1-3]. At the same time, culling is a way to increase herd productivity and profitability, as keeping diseased and unproductive cows might result in lower herd milk production and deteriorated reproduction. Keeping cows too long in a herd might also impair the herd's genetic improvement [3]. In order to maximize profitability, the proportion of

\footnotetext{
* Correspondence: Triin.Rilanto@emu.ee

${ }^{1}$ Institute of Veterinary Medicine and Animal Sciences, Estonian University of Life Science, Kreutzwaldi 62, 51006 Tartu, Estonia

Full list of author information is available at the end of the article
}

voluntary culling (selling for dairy purposes or culling due to low production) should be highest among the total culling rate $[1,3,4]$. Previous studies indicate an ascending trend in the proportion of involuntary culling $[4,5]$. Culling rate, especially the proportion of involuntary culls, may also be considered as an animal welfare indicator $[4,6,7]$.

During the last decades, culling rates have not increased; however, the longevity of cows has declined worldwide $[8,9]$. In Estonia, the average productive age of culled cows has decreased from 1113 to 1051 days between 2013 and 2018, respectively [10, 11]. Longer productive lifetime would result in lower replacement costs, the opportunity to sell heifers $[12,13]$ and the possibility

(c) The Author(s). 2020 Open Access This article is licensed under a Creative Commons Attribution 4.0 International License, which permits use, sharing, adaptation, distribution and reproduction in any medium or format, as long as you give appropriate credit to the original author(s) and the source, provide a link to the Creative Commons licence, and indicate if changes were made. The images or other third party material in this article are included in the article's Creative Commons licence, unless indicated otherwise in a credit line to the material. If material is not included in the article's Creative Commons licence and your intended use is not permitted by statutory regulation or exceeds the permitted use, you will need to obtain permission directly from the copyright holder. To view a copy of this licence, visit http://creativecommons.org/licenses/by/4.0/ The Creative Commons Public Domain Dedication waiver (http://creativecommons.org/publicdomain/zero/1.0/) applies to the data made available in this article, unless otherwise stated in a credit line to the data. 
of increasing the proportion of voluntary culling, bearing a desirable effect on herd profitability [14]. Return of the rearing costs up to first calving are covered roughly by the start of the second lactation [13, 15]. Milk yield reaches the highest level after the third lactation [11], meaning that culling young cows is especially undesirable. Importantly, short lifespan is against consumers' expectations and is also associated with more detrimental environmental impacts [16]. Culling reasons have changed over the last decades, referring to the proportion of culling due to voluntary reasons (e.g., low milk yield), which has decreased and shifted into rather disease-related reasons [9].

Estonia is located in Northern Europe on the coast of Baltic Sea. Having a temperate climate condition the average temperature is $+5 \mathrm{C}^{\circ}$ being $-4 \ldots-5 \mathrm{C}^{\circ}$ in winter months and $15 \quad \ldots \quad 18 \quad \mathrm{C}^{\circ}$ in summer months. Estonian dairy cow population constitutes approximately 85,000 dairy cows, with roughly $67 \%$ of the dairy cows being housed in farms with more than 300 cows in 2018 (Estonian Agricultural Registers and Information Board, 2018). The average milk yield of Estonian dairy cows was $9785 \mathrm{~kg}$ in 2018 (Estonian Livestock Performance Recording Yearbook, 2018), taking second place in the EU (Eurostat, 2019). The majority of large Estonian dairy farms are loosehoused open-air barns using modern equipment and technology managed by hired labour. The Estonian dairy cow population is endemically infected with many cattle pathogens, including bovine herpesvirus 1 , bovine respiratory syncytial virus and bovine viral diarrhea virus [17], digital dermatitis [18] as well as with main contagious mastitis pathogens Staphylococcus aureus, Streptococcus agalactiae and Mycoplasma bovis [19]. Due to these population characteristics, the results of previous studies investigating reasons and risk factors for dairy cow culling might not apply to these herds. Due to worldwide intensification of dairy production [20], the Estonian dairy cow population could serve as a valuable example, representing herds with high production level and mostly intensive keeping conditions.

In order to make use of opportunities that may be afforded by increasing cow longevity, there is a need for an overview about the main reasons as well as the risk factors that influence the probability of culling. This information would allow for the establishment of betterfocused hypotheses for further studies that aim to reveal causal associations between animal and herd-level risk factors and dairy cow longevity. The aim of the present study was to analyse the culling rates of Estonian dairy cows, identify the frequency of farmers' stated reasons for dairy cow culling, and investigate risk factors for cow culling.

\section{Results}

\section{Descriptive statistics}

The final datasets used for the analyses included the data of 263,934 lactations of 154,057 cows reared in 410 herds. In the dataset, 71,442 (46.4\%) cows had a single lactation, 55,689 (36.2\%) cows had two lactations, 26,590 (17.2\%) cows had three, and $336(0.2 \%)$ cows had four lactations, whereas 67,684 primiparous cows were repeated in the multiparous cow dataset. In total, 86,373 lactation level records of primiparous cows reared in 409 herds, and 177,561 lactations of 109,295 multiparous cows from 410 herds were analysed separately. The overall culling rate (CR) of Estonian dairy cows was 26.24 (95\% CI 26.02; 26.46) per 100 cow-years. Among primiparous cows 3348 (3.9\%) died on-farm, 95 (0.1\%) were euthanized, 8044 (9.3\%) cows were transported to slaughter, 3544 (4.1\%) were sold to another herd and four were lost during the lactation level observation period resulting in a CR of 15.95 (95\% CI 15.66; 16.24) per 100 cow-years. In the multiparous cow dataset, there were 10,756 (6.1\%) death records, $260(0.2 \%)$ cows were euthanized, 31,248 (17.6\%) were transported to slaughter, 12,144 (6.8\%) were sold and 25 cows were lost. The CR was 31.83 (95\% CI 31.52; 32.12) per 100 cow-years among multiparous cows. The hazard of culling was significantly higher in multiparous cows compared to primiparous cows in the univariable Weibull random-effect model (hazard rate ratio $(\mathbf{H R})=2.04,95 \%$ CI $2.00 ; 2.08$, $p<0.001$ ) (Fig. 1).

The culling risk was highest during the early postpartum period (Figs. 1 and 2). By 30 days after calving the survivor probability of primiparous cows was 0.96 (95\% CI 0.96; 0.97) and 0.94 (95\% CI 0.94; 0.94) in multiparous cows. The average survival probability was $4.42 \%$ lower in multiparous cows compared to primiparous cows at 100 days of lactation. The survival probability dropped from 0.91 ( $95 \%$ CI $0.91 ; 0.91)$ to $0.89(95 \%$ CI $0.88 ; 0.89)$ in primiparous cows and from 0.83 (95\% CI $0.83 ; 0.83)$ to 0.78 (95\% CI $0.78 ; 0.78)$ in multiparous cows between 200 to 305 days after calving (DAC), respectively. The survival probability declined by 16.1 and 23.5\% between 305 and 600 DAC in primiparous and multiparous cows, respectively (Fig. 1). Around one year after calving, a small increase in the number of culling events was observed among primiparous cows and a stabilisation of continuous decrease of number of culling events over lactation was also identified in multiparous cows at that time (Fig. 2).

\section{Farmers' stated reasons for culling}

Culling reason was missing for 95 and 366 culling events in primiparous and multiparous cows, respectively. Main causes of culling due to death and slaughter were reported as feet/claw disorders (26.4\% of culled cows), 


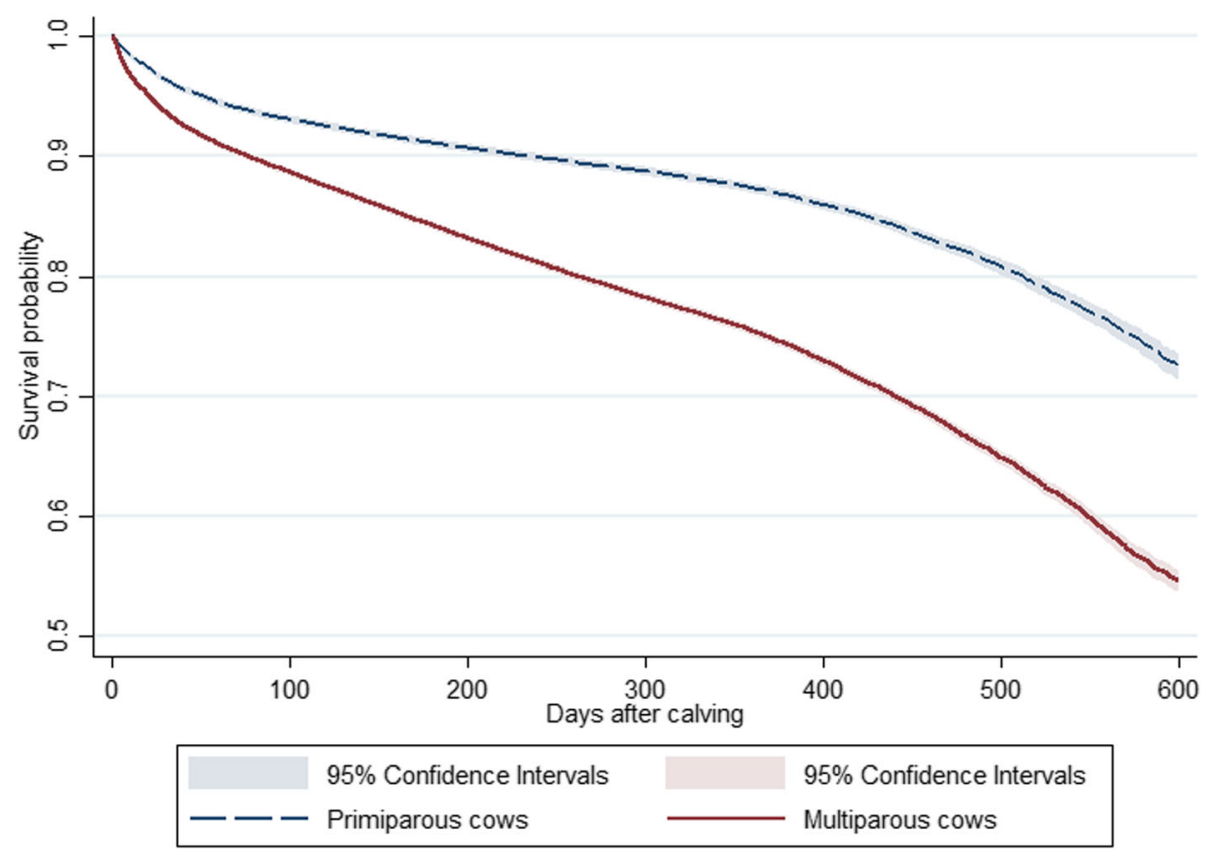

Fig. 1 Kaplan-Meier survival curve for Estonian primiparous and multiparous cows followed from calving to culling (on-farm death, euthanasia or slaughter) or right censoring in 86,373 primiparous and 109,295 multiparous cows in the period between January 1, 2013 to December 31, 2015

udder disorders $(22.6 \%)$, metabolic and digestive disorders $(18.1 \%)$, and fertility problems $(12.5 \%)$. The importance of fertility problems as the reason for culling decreased after the second parity (Table 1).

In total, 50.7 and $46.5 \%$ of the culling events occurred during the first 100 DAC in primiparous and multiparous cows, respectively. Roughly one-third (33.9\%) of the cullings took place at more than 200 DAC. Metabolic and digestive disorders were more prevalent up to 100 DAC (17.1 and $31.7 \%$ in primiparous and multiparous cows, respectively) compared to later stages of lactation (11.5 and $11.1 \%$ in primiparous
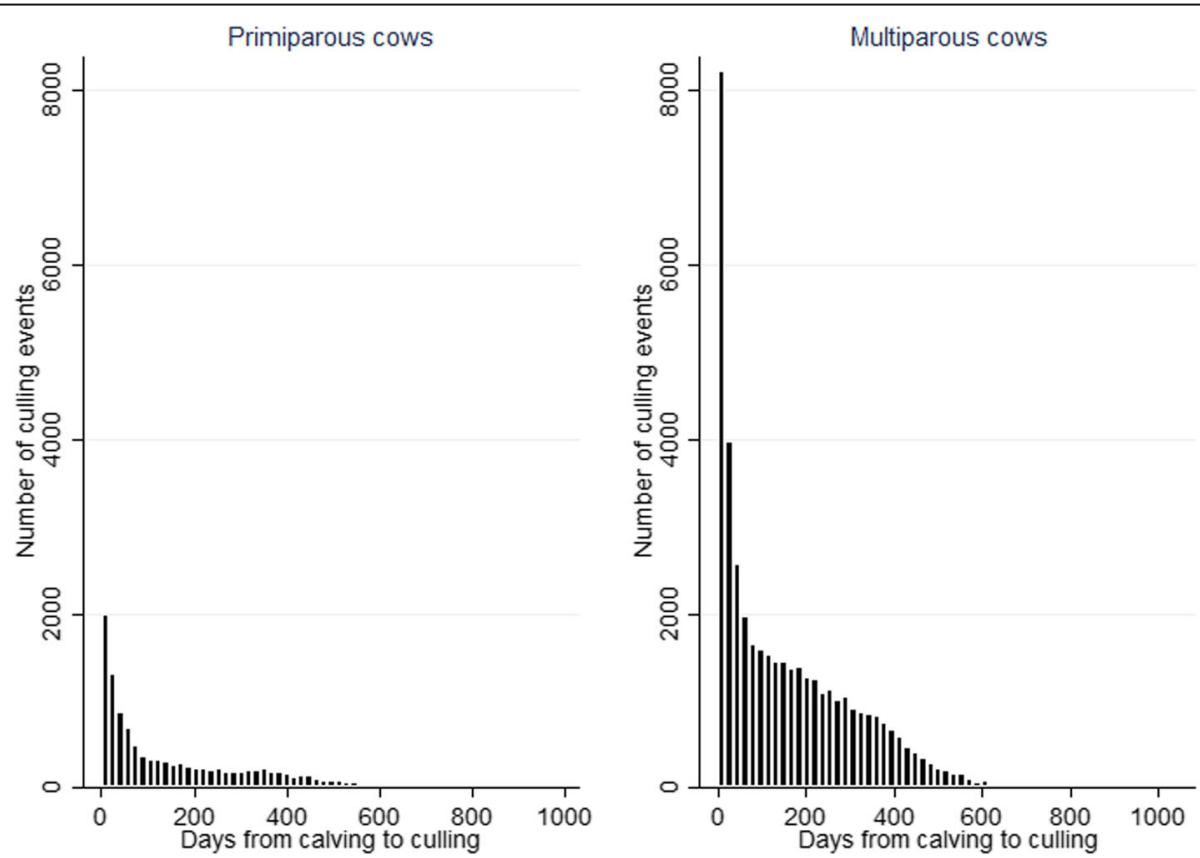

Fig. 2 Distribution of culling events (on-farm mortality, euthanasia or slaughter) over lactation in 11,491 Estonian primiparous and 42,289 multiparous culled cows between January 1,2013 to December 31, 2015 
Table 1 Distribution of farmers' stated reasons for Estonian culled dairy cows due to death and slaughter over parities in years 2013 to 2015

\begin{tabular}{|c|c|c|c|c|c|c|c|}
\hline \multirow[b]{2}{*}{ Reason of culling } & \multicolumn{7}{|l|}{ Parity } \\
\hline & $1(\%)^{a}$ & $2(\%)^{a}$ & $3(\%)^{a}$ & $4(\%)^{a}$ & $5(\%)^{a}$ & $\geq 6(\%)^{a}$ & Total $(\%)^{a}$ \\
\hline Feet/claw disorders & $2875(25.2)$ & $2953(26.3)$ & $2913(27.1)$ & $2355(27.3)$ & $1499(26.6)$ & $1487(26.2)$ & $14,082(26.4)$ \\
\hline Respiratory and infectious diseases & $208(1.8)$ & $168(1.5)$ & $139(1.3)$ & $77(0.9)$ & $46(0.8)$ & $29(0.5)$ & $667(1.3)$ \\
\hline Metabolic and digestive disorders & $1527(13.4)$ & $1932(17.2)$ & $2193(20.4)$ & $1855(21.5)$ & $1197(21.2)$ & $950(16.8)$ & $9654(18.1)$ \\
\hline Fertility problems & $1736(15.2)$ & $1782(15.9)$ & $1322(12.3)$ & $865(10.0)$ & $519(9.2)$ & $457(8.1)$ & $6681(12.5)$ \\
\hline Dystocia & $561(4.9)$ & $232(2.1)$ & $211(2.0)$ & $185(2.2)$ & $142(2.5)$ & $116(2.1)$ & $1447(2.7)$ \\
\hline Trauma and accident & $615(5.4)$ & $488(4.3)$ & $403(3.7)$ & $266(3.1)$ & $157(2.8)$ & $138(2.4)$ & $2067(3.9)$ \\
\hline Udder disorders & $2046(18.0)$ & $2404(21.4)$ & $2569(23.9)$ & $2157(25.0)$ & $1455(25.8)$ & $1418(25.0)$ & $12,049(22.6)$ \\
\hline Low milk yield & $930(8.2)$ & $525(4.7)$ & 378 (3.5) & $276(3.2)$ & $175(3.1)$ & $168(3.0)$ & $2452(4.6)$ \\
\hline Age & $1(0.01)$ & $2(0.02)$ & $9(0.1)$ & $38(0.4)$ & $92(1.6)$ & $552(9.7)$ & $694(1.3)$ \\
\hline Other ${ }^{b}$ & 897 (7.9) & $749(6.7)$ & $630(5.9)$ & $540(6.3)$ & $359(6.4)$ & $351(6.2)$ & $3526(6.6)$ \\
\hline Total & $11,396(21.4)^{c}$ & $11,235(21.1)^{c}$ & $10,767(20.2)^{c}$ & $8614(16.2)^{c}$ & $5641(10.6)^{c}$ & $5666(10.6)^{c}$ & $53,319(100.0)$ \\
\hline
\end{tabular}

${ }^{a} \mathrm{n}$ (\% of total $\mathrm{n}$ culled in respective parity)

banimal lost, bad temperament, bad milking, selling, other reasons

c $\mathrm{n}(\%$ of total $\mathrm{n}$ culled)

and multiparous cows, respectively in 101-200 DAC). Feet and claw disorders (30.9 and 33.1\% in primiparous and multiparous cows, respectively) and udder disorders (25.0 and $35.0 \%$ in primiparous and multiparous cows, respectively) were most common reasons for culling in the middle of the lactation period. Fertility problems were the primary reasons for culling in the late lactation stage ( $\geq 200$ DAC), comprising 38.2 and $28.1 \%$ of all culls among primiparous and multiparous cows, respectively. Across all culling reasons, metabolic disorders were nearly twice as frequently the cause of culling in multiparous cows compared to primiparous cows. In primiparous cows, dystocia and low milk yield both constituted roughly $9 \%$ of all culling reasons during the first 100 DAC, being higher than that reported in multiparous cows (4.1 and $2.0 \%$, respectively) (Table 2 ).

\section{Animal-level risk factors for culling}

Descriptive statistics and univariable associations between continuous and categorical predictor variables and culling are presented in Supplementary Tables 1A and $1 \mathrm{~B}$, respectively.

Several culling risk factors were common for primiparous and multiparous cows. Estonian Red and Estonian

Table 2 Distribution of farmers' stated reasons for Estonian culled dairy cows due to death and slaughter over lactation stages in years 2013 to 2015

\begin{tabular}{|c|c|c|c|c|c|c|}
\hline \multirow[b]{2}{*}{ Reason of culling } & \multicolumn{2}{|c|}{ Primiparous cows } & \multirow[b]{2}{*}{$\geq 200 \mathrm{DAC} C^{\mathrm{a}, \mathrm{b}}$} & \multicolumn{2}{|c|}{ Multiparous cows } & \multirow[b]{2}{*}{$\geq 200 \mathrm{DAC} C^{\mathrm{a}, \mathrm{b}}$} \\
\hline & $<100 D A C^{a, b}$ & $101-200 D^{2} C^{a, b}$ & & $<100 D A^{a, b}$ & $101-200 D^{2} C^{a, b}$ & \\
\hline Feet/claw disorders & $1575(27.2)$ & 539 (30.9) & $761(19.7)$ & $4990(25.6)$ & $2721(33.1)$ & $3496(24.6)$ \\
\hline Respiratory and infectious diseases & $95(1.6)$ & $44(2.5)$ & $69(1.8)$ & $258(1.3)$ & $93(1.1)$ & $108(0.8)$ \\
\hline Metabolic and digestive disorders & $991(17.1)$ & $200(11.5)$ & $336(8.7)$ & $6177(31.7)$ & $913(11.1)$ & $1037(7.3)$ \\
\hline Fertility problems & $173(3.0)$ & $85(4.9)$ & $1478(38.2)$ & $615(3.2)$ & $332(4.0)$ & $3998(28.1)$ \\
\hline Dystocia & $520(9.0)$ & $2(0.1)$ & $39(1.0)$ & $793(4.1)$ & $2(0.02)$ & $91(0.6)$ \\
\hline Trauma and accident & $326(5.6)$ & $107(6.1)$ & $182(4.7)$ & $826(4.2)$ & $256(3.2)$ & $370(2.6)$ \\
\hline Udder disorders & $1120(19.4)$ & $437(25.0)$ & $489(12.7)$ & $4140(21.2)$ & $2876(35.0)$ & 2987 (21.0) \\
\hline Low milk yield & $526(9.1)$ & $159(9.1)$ & $245(6.4)$ & $381(2.0)$ & $383(4.7)$ & $758(5.3)$ \\
\hline Age & $0(0)$ & $0(0)$ & $1(0.003)$ & $133(0.7)$ & $140(1.7)$ & $420(3.0)$ \\
\hline Other ${ }^{c}$ & 456 (7.9) & $174(10.0)$ & 267 (6.9) & $1181(6.0)$ & $494(6.0)$ & $954(6.7)$ \\
\hline Total & $5782(50.7)^{d}$ & $1747(15.3)^{d}$ & $3867(33.9)^{4}$ & $19,494(46.5)^{\mathrm{e}}$ & $8210(19.6)^{\mathrm{e}}$ & $14,219(33.9)^{\mathrm{e}}$ \\
\hline
\end{tabular}

${ }^{\mathrm{a} D A C}$ - days after calving

${ }^{\mathrm{b}} \mathrm{n}$ (\% of total $\mathrm{n}$ culled during specific lactation stage)

canimal lost, bad temperament, bad milking, selling, other reasons

dproportion of primiparous cows culled during specific lactation stage

eproportion of multiparous cows culled during specific lactation stage 
Native breed cows had significantly lower culling hazard compared to Estonian Holstein breed cows $(\mathrm{HR}=0.92$, 95\% CI $0.85 ; 0.98$ and $\mathrm{HR}=0.84,95 \%$ CI $0.81 ; 0.87$ in primiparous and multiparous cows, respectively). Higher milk yield breeding value was a protective factor for culling. In primiparous cows, the culling hazard was significantly lower in $2015(\mathrm{HR}=0.90,95 \%$ CI 0.85 ; 0.94) compared to 2013. In multiparous cows, the culling hazard was significantly higher in $2014(\mathrm{HR}=1.08,95 \% \mathrm{CI}$ $1.06 ; 1.10)$ and $2015(\mathrm{HR}=1.05,95 \%$ CI $1.02 ; 1.07)$ compared to 2013. Having a stillborn calf $(\mathrm{HR}=1.45,95 \% \mathrm{CI}$ 1.37 ; 1.54 and $\mathrm{HR}=1.74,95 \%$ CI $1.68 ; 1.81$ in primiparous and multiparous cows, respectively), abortion (HR = $2.69,95 \%$ CI 2.34; 3.10 in multiparous cows) or twins/ triplets $(\mathrm{HR}=1.31,95 \% \mathrm{CI} 1.05 ; 1.63$ and $\mathrm{HR}=1.35$, 95\% CI 1.29; 1.42 in primiparous and multiparous cows, respectively) were associated with a higher risk for culling compared to giving birth to a single female calf. In multiparous cows, the culling hazard was also higher in cows that gave birth to a male calf compared to a female calf $(\mathrm{HR}=1.05,95 \% \mathrm{CI} 1.03 ; 1.07)$. There was a timedependent effect of assisted calving to culling hazard the negative effect of assisted calving on culling hazard was higher during the first seven days post-partum compared to a later period. Also, higher age at first calving was associated with a higher culling hazard $(H R=1.07$, 95\% CI 1.06; 1.07 and HR $=1.02,95 \%$ CI $1.02 ; 1.03$ in primiparous and multiparous cows, respectively) but the association was not linear (Tables 3 and 4).

In multiparous cows, the culling hazard increased with parity. Somatic cell count (SCC) over 200,000 per ml and lower milk yield at last test-milking before dry-off were factors associated with a higher culling hazard during the following lactation $(\mathrm{HR}=1.21,95 \%$ CI $1.18 ; 1.23$ and $\mathrm{HR}=0.99,95 \%$ CI $0.989 ; 0.99$, respectively). Robot milking system at last test-milking before dry-off was a protective factor for culling ( $\mathrm{HR}=0.83,95 \%$ CI 0.78 ; 0.89) compared to other milking methods (Tables 3 and 4).

In addition, lower milk yield ( $\mathrm{HR}=0.96,95 \% \mathrm{CI} 0.956$; $0.958)$, somatic cell count $\geq 200,000$ cells $/ \mathrm{ml}(\mathrm{HR}=1.31$, $95 \%$ CI 1.28 ; 1.34) and milk fat/protein ratio $\geq 1.5$ (HR = $1.23,95 \%$ CI $1.20 ; 1.26)$ in first test-milking after calving were associated with a higher culling risk during the lactation. Using automatic milking system or milking cows three times a day at first test-milking were protective for cow culling probability during the lactation compared to milking cows twice a day ( $\mathrm{HR}=0.57,95 \%$ CI $0.53 ; 0.61$ and $\mathrm{HR}=0.79,95 \%$ CI 0.74; 0.84, respectively) (Table 5).

\section{Herd-level factors associated with culling}

Cow culling hazard was higher in herds that reduced their number of cows by more than $15 \%$ within the three study years $(\mathrm{HR}=1.56,95 \% \mathrm{CI} 1.22 ; 2.00$ and $\mathrm{HR}=1.33$, $95 \%$ CI $1.15 ; 1.54$ compared to stable herd size in primiparous and multiparous cows, respectively), whereas expanding herd size (increase of number of cows $>15 \%)$ had a protective effect on culling ( $\mathrm{HR}=$ $0.61,95 \%$ CI $0.47 ; 0.80$ and $\mathrm{HR}=0.82,95 \%$ CI 0.70 ; $0.95)$. On average, the culling hazard was higher in larger herds. Increase of herd size by 50 cows was associated with on average $4 \%$ higher culling hazard $(\mathrm{HR}=1.04$, $95 \%$ CI 1.02; 1.05) in primiparous cows and $2 \%(\mathrm{HR}=$ 1.02 , 95\% CI 1.01; 1.03) higher culling hazard in multiparous cows (Tables 3 and 4).

The culling hazard was also negatively associated with herd average lactation number. Longer herd average interval from calving to insemination $(\mathrm{HR}=0.99,95 \% \mathrm{CI}$ $0.985 ; 0.992)$ and longer herd average calving interval ( $\mathrm{HR}=0.97,95 \%$ CI $0.95 ; 0.98)$ was associated with lower culling hazard in primiparous cows and multiparous cows, respectively (Tables 3 and 4). In primiparous cows, the culling risk was higer for cows in herds with higher first insemination conception rate $(\mathrm{HR}=1.01,95 \% \mathrm{CI}$ 1.01 ; 1.02) (Table 3). On average, for every $500 \mathrm{~kg}$ increase in the herd's average milk yield, the culling hazard was $4 \%$ higher $(\mathrm{HR}=1.04,95 \% \mathrm{CI} 1.02 ; 1.06)$ in multiparous cows (Table 4).

The graphical assessment confirmed meeting the proportional hazard assumption of tested categorical variables in a $\log$ cumulative hazard plot as well as the overall fit of the models assessed by plotting Cox-Snell residuals against the cumulative hazards of individual observations at their failure times.

\section{Discussion}

\section{Culling rates and farmers' stated reasons for culling}

There is no single optimal culling rate that is applicable to all herds for all years due to a variety of economic factors, farm capacities, individual cow factors, morbidity and mortality rates within the herd, availability of replacements, biosecurity considerations, etc. [1]. Not all studies have presented the culling rates due to death/ slaughter excluding sales. In the current study, the average culling rate of Estonian dairy cows was 26.24 per 100 animal-years, excluding selling from the culling definition. In selected regions of the United States, the average culling rate was $31.6 \%$ in 1999 [3] but was $27.7 \%$ in Pennsylvanian herds in 2005 [21]. In Canada, Haine et al. [22] reported an average culling rate of $32 \%$ over the 2001-2010 decade and a dairy sell rate by 60 days in milk of $3.2 \%$. The average culling rate of cows due to slaughter/death was $25.4 \%$, ranging between $23 \%$ (in 2007) to 28\% (in 2010) in Dutch dairy herds [23]. This shows that, on average, culling rates of the Estonian dairy cow population are mostly comparable to that reported in other countries.

Farmers' stated reasons for culling were analysed in the present study due to the absence of more sound 
Table 3 Results of multivariable random-effect Weibull model for risk factors of culling in 85,765 primiparous dairy cows (herds $n=389$ )

\begin{tabular}{|c|c|c|c|c|c|c|}
\hline Variable & Category & $N^{a, b}$ & $\begin{array}{l}\text { Hazard Rate } \\
\text { Ratio }\end{array}$ & $\begin{array}{l}95 \% \text { Confidence } \\
\text { Intervals }\end{array}$ & P-value & $\begin{array}{l}\text { Likelihood ratio } \\
\text { test } p \text {-value }\end{array}$ \\
\hline \multicolumn{7}{|l|}{ Animal level variables } \\
\hline \multirow[t]{2}{*}{ Breed $^{\mathrm{a}}$} & Estonian Holstein & 70,508 & 1 & & & 0.018 \\
\hline & $\begin{array}{l}\text { Estonian Red and } \\
\text { Estonian Native }\end{array}$ & 15,257 & 0.92 & $0.85 ; 0.98$ & 0.018 & \\
\hline \multirow[t]{5}{*}{ Relative milk yield breeding value ${ }^{a}$} & $<90$ & 17,622 & 1 & & & $<0.001$ \\
\hline & $90-96$ & 20,022 & 0.66 & $0.63 ; 0.71$ & $<0.001$ & \\
\hline & $97-104$ & 18,065 & 0.48 & $0.45 ; 0.52$ & $<0.001$ & \\
\hline & $\geq 105$ & 21,320 & 0.37 & $0.35 ; 0.40$ & $<0.001$ & \\
\hline & Not estimated & 8736 & 14.50 & $13.74 ; 15.31$ & $<0.001$ & \\
\hline \multirow[t]{3}{*}{ Calving year $^{\mathrm{a}}$} & 2013 & 27,904 & 1 & & & $<0.001$ \\
\hline & 2014 & 29,368 & 1.01 & $0.97 ; 1.06$ & 0.536 & \\
\hline & 2015 & 28,493 & 0.90 & $0.85 ; 0.94$ & $<0.001$ & \\
\hline \multirow[t]{5}{*}{ Calf $^{a}$} & Female & 38,482 & 1 & & & $<0.001$ \\
\hline & Male & 36,502 & 1.04 & $0.996 ; 1.081$ & 0.080 & \\
\hline & Stillbirth & 9972 & 1.45 & $1.37 ; 1.54$ & $<0.001$ & \\
\hline & Twins/triplets & 480 & 1.31 & $1.05 ; 1.63$ & 0.015 & \\
\hline & Abortion & 329 & 0.67 & $0.50 ; 0.91$ & 0.011 & \\
\hline \multirow[t]{4}{*}{ Assisted calving $x$ period ${ }^{b}$} & No, $<7$ days & 70,351 & 1 & & & $<0.001$ \\
\hline & No, $>7$ days & 69,176 & 1.13 & $1.04 ; 1.23$ & 0.004 & \\
\hline & Yes, $<7$ days & 15,414 & 2.10 & $1.81 ; 2.36$ & $<0.001$ & \\
\hline & Yes, $>7$ days & 14,939 & 1.34 & $1.22 ; 1.48$ & $<0.001$ & \\
\hline Age at first calving (months) (centered) & & & 1.07 & $1.06 ; 1.07$ & $<0.001$ & $<0.001$ \\
\hline $\begin{array}{l}\text { Square term centered value of age } \\
\text { at first calving (months) }\end{array}$ & & & 0.99 & $0.994 ; 0.995$ & $<0.001$ & $<0.001$ \\
\hline \multicolumn{7}{|l|}{ Herd-level variables } \\
\hline \multirow{5}{*}{$\begin{array}{l}\text { Change of herd size from } 2013 \\
\text { to } 2015^{\mathrm{a}}\end{array}$} & No change $( \pm 5 \%)$ & 39,143 & 1 & & & $<0.001$ \\
\hline & Decrease $>5$ to $15 \%$ & 12,904 & 1.28 & $1.001 ; 1.631$ & 0.049 & \\
\hline & Decrease > 15\% & 8499 & 1.56 & $1.22 ; 2.00$ & $<0.001$ & \\
\hline & Increase > 5 to $15 \%$ & 13,591 & 0.79 & $0.62 ; 1.01$ & 0.060 & \\
\hline & Increase > 15\% & 11,628 & 0.61 & $0.47 ; 0.80$ & $<0.001$ & \\
\hline $\begin{array}{l}\text { Herd average number of cows } \\
\text { (increase by } 50 \text { cows) }\end{array}$ & & & 1.04 & $1.02 ; 1.05$ & $<0.001$ & $<0.001$ \\
\hline $\begin{array}{l}\text { Herd average interval from calving } \\
\text { to insemination (days) }\end{array}$ & & & 0.99 & $0.985 ; 0.992$ & $<0.001$ & $<0.001$ \\
\hline $\begin{array}{l}\text { Herd average first insemination } \\
\text { conception rate }(\%)\end{array}$ & & & 1.01 & $1.01 ; 1.02$ & $<0.001$ & $<0.001$ \\
\hline $\begin{array}{l}\text { Herd average number of } \\
\text { lactations (years) }\end{array}$ & & & 0.41 & $0.33 ; 0.51$ & $<0.001$ & $<0.001$ \\
\hline \multirow[t]{4}{*}{ Region $^{\mathrm{a}, \mathrm{c}}$} & North-East & 36,651 & 1 & & & 0.018 \\
\hline & South-East & 17,235 & 0.85 & $0.71 ; 1.02$ & 0.086 & \\
\hline & South-West & 19,091 & 1.14 & $0.98 ; 1.32$ & 0.087 & \\
\hline & North-West & 12,788 & 1.04 & $0.87 ; 1.24$ & 0.665 & \\
\hline
\end{tabular}

Shape parameter $p=0.82$

${ }^{a}$ number of animals in each category

${ }^{b}$ number of observations in each category after splitting the observations in 7th day post-calving

'Northeast Estonia: Ida-Viru, Lääne-Viru, Jõgeva, Järva county; Southeast Estonia: Tartu, Valga, Võru, Põlva county; Southwest Estonia: Pärnu,

Viljandi, Saare county; Northwest Estonia: Harju, Rapla, Lääne, Hiiu county 
Table 4 Results of multivariable random-effect Weibull model for risk factors of culling in 107,835 multiparous dairy cows in 173,773 lactations (herds $n=409$ )

\begin{tabular}{|c|c|c|c|c|c|c|}
\hline Variable & Category & $\mathrm{N}^{\mathrm{a}, \mathrm{b}}$ & $\begin{array}{l}\text { Hazard Rate } \\
\text { Ratio }\end{array}$ & $\begin{array}{l}95 \% \text { Confidence } \\
\text { Intervals }\end{array}$ & P-value & $\begin{array}{l}\text { Likelihood ratio } \\
\text { test } p \text {-value }\end{array}$ \\
\hline \multicolumn{7}{|l|}{ Animal level variables } \\
\hline \multirow[t]{2}{*}{ Breed $^{a}$} & Estonian Holstein & 85,879 & 1 & & & \\
\hline & $\begin{array}{l}\text { Estonian Red and } \\
\text { Estonian Native }\end{array}$ & 21,956 & 0.84 & $0.81 ; 0.87$ & $<0.001$ & $<0.001$ \\
\hline \multirow[t]{5}{*}{ Relative milk yield breeding value ${ }^{a}$} & $<90$ & 23,731 & 1 & & & $<0.001$ \\
\hline & $90-96$ & 23,607 & 0.97 & $0.94 ; 0.997$ & 0.028 & \\
\hline & $97-104$ & 27,319 & 0.94 & $0.91 ; 0.97$ & $<0.001$ & \\
\hline & $\geq 105$ & 27,704 & 0.88 & $0.86 ; 0.91$ & $<0.001$ & \\
\hline & Not estimated & 5474 & 0.94 & $0.88 ; 0.99$ & $<0.001$ & \\
\hline \multirow[t]{3}{*}{ Calving year ${ }^{b}$} & 2013 & 56,644 & 1 & & & $<0.001$ \\
\hline & 2014 & 58,792 & 1.08 & $1.06 ; 1.10$ & $<0.001$ & \\
\hline & 2015 & 58,337 & 1.05 & $1.02 ; 1.07$ & 0.001 & \\
\hline \multirow[t]{2}{*}{ Abortion in previous lactation ${ }^{b}$} & No & 172,949 & 1 & & & \\
\hline & Yes & 824 & 0.86 & $0.76 ; 0.98$ & 0.025 & 0.025 \\
\hline $\begin{array}{l}\text { Previous calving interval (increase } \\
\text { of ten days, in months) (centered) }\end{array}$ & & & 1.03 & $1.03 ; 1.04$ & $<0.001$ & $<0.001$ \\
\hline $\begin{array}{l}\text { Square term centered value of previous } \\
\text { calving interval (increase of ten days, } \\
\text { in months) (centered) }\end{array}$ & & & 0.99998 & $0.99983 ; 0.99994$ & $<0.001$ & $<0.001$ \\
\hline \multirow[t]{6}{*}{ Parity $^{\mathrm{b}}$} & Second & 66,191 & 1 & & & $<0.001$ \\
\hline & Third & 46,171 & 1.38 & $1.34 ; 1.42$ & $<0.001$ & \\
\hline & Fourth & 29,511 & 1.81 & $1.76 ; 1.87$ & $<0.001$ & \\
\hline & Fifth & 16,868 & 2.22 & $2.14 ; 2.29$ & $<0.001$ & \\
\hline & Sixth & 8566 & 2.49 & $2.39 ; 2.60$ & $<0.001$ & \\
\hline & $\geq$ Seventh & 6466 & 3.13 & $2.99 ; 3.28$ & $<0.001$ & \\
\hline \multirow[t]{5}{*}{ Calf } & Female & 75,311 & 1 & & & $<0.001$ \\
\hline & Male & 82,247 & 1.05 & $1.03 ; 1.07$ & $<0.001$ & \\
\hline & Stillbirth & 9063 & 1.74 & $1.68 ; 1.81$ & $<0.001$ & \\
\hline & Twins/triplets & 6655 & 1.35 & $1.29 ; 1.42$ & $<0.001$ & \\
\hline & Abortion & 497 & 2.69 & $2.34 ; 3.10$ & $<0.001$ & \\
\hline \multirow[t]{4}{*}{ Assisted calving $\mathrm{x}$ period ${ }^{c}$} & No, $<7$ days & 159,057 & 1 & & & $<0.001$ \\
\hline & No, $>7$ days & 154,449 & 0.51 & $0.49 ; 0.53$ & $<0.001$ & \\
\hline & Yes, $<7$ days & 14,670 & 2.34 & $2.16 ; 2.55$ & $<0.001$ & \\
\hline & Yes, $>7$ days & 13,838 & 0.59 & $0.56 ; 0.62$ & $<0.001$ & \\
\hline \multirow{2}{*}{$\begin{array}{l}\text { Milk somatic cell count at last test- } \\
\text { milking in previous lactation }\left({ }^{*} 1000 / \mathrm{ml}\right)^{b}\end{array}$} & $<200$ & & 1 & & & \\
\hline & $\geq 200$ & & 1.21 & $1.18 ; 1.23$ & $<0.001$ & $<0.001$ \\
\hline $\begin{array}{l}\text { Days in milk during last test-milking in } \\
\text { previous lactation (days) })^{b}\end{array}$ & & & 0.998 & $0.9978 ; 0.998$ & $<0.001$ & $<0.001$ \\
\hline $\begin{array}{l}\text { Milk yield at last test-milking in previous } \\
\text { lactation }(\mathrm{kg})^{b}\end{array}$ & & & 0.99 & $0.989 ; 0.99$ & $<0.001$ & $<0.001$ \\
\hline \multirow{3}{*}{$\begin{array}{l}\text { Milking method at last test-milking of } \\
\text { previous lactation }^{b}\end{array}$} & Milking twice a day & & 1 & & & $<0.001$ \\
\hline & $\begin{array}{l}\text { Milking three times } \\
\text { a day }\end{array}$ & & 0.96 & $0.89 ; 1.04$ & 0.303 & \\
\hline & Robot milking & & 0.83 & $0.78 ; 0.89$ & $<0.001$ & \\
\hline \multicolumn{3}{|l|}{ Age at first calving (months) (centered) } & 1.02 & $1.02 ; 1.03$ & $<0.001$ & $<0.001$ \\
\hline
\end{tabular}


Table 4 Results of multivariable random-effect Weibull model for risk factors of culling in 107,835 multiparous dairy cows in 173,773 lactations (herds $n=409$ ) (Continued)

\begin{tabular}{|c|c|c|c|c|c|c|}
\hline Variable & Category & $\mathrm{N}^{\mathrm{a}, \mathrm{b}}$ & $\begin{array}{l}\text { Hazard Rate } \\
\text { Ratio }\end{array}$ & $\begin{array}{l}95 \% \text { Confidence } \\
\text { Intervals }\end{array}$ & P-value & $\begin{array}{l}\text { Likelihood ratio } \\
\text { test } p \text {-value }\end{array}$ \\
\hline $\begin{array}{l}\text { Square term centered value of age at } \\
\text { first calving (months) }\end{array}$ & & & 0.9995 & $0.9991 ; 0.9999$ & 0.024 & 0.024 \\
\hline \multicolumn{7}{|l|}{ Herd level variables } \\
\hline \multirow[t]{5}{*}{ Change of herd size from 2013 to $2015^{a}$} & No change ( $\pm 5 \%)$ & 48,548 & 1 & & & $<0.001$ \\
\hline & Decrease $>5$ to $15 \%$ & 16,286 & 1.06 & $0.92 ; 1.21$ & 0.444 & \\
\hline & Decrease $>15 \%$ & 12,204 & 1.33 & $1.15 ; 1.54$ & $<0.001$ & \\
\hline & Increase > 5 to $15 \%$ & 16,922 & 0.89 & $0.77 ; 1.02$ & 0.091 & \\
\hline & Increase > 15\% & 13,875 & 0.82 & $0.70 ; 0.95$ & 0.008 & \\
\hline $\begin{array}{l}\text { Herd average calving interval } \\
\text { (increase by } 10 \text { days) }\end{array}$ & & & 0.97 & $0.95 ; 0.98$ & $<0.001$ & $<0.001$ \\
\hline $\begin{array}{l}\text { Herd average number of cows } \\
\text { (increase by } 50 \text { cows) }\end{array}$ & & & 1.02 & $1.01 ; 1.03$ & 0.002 & 0.002 \\
\hline $\begin{array}{l}\text { Herd average milk yield (increase } \\
\text { by } 500 \mathrm{~kg} \text { ) }\end{array}$ & & & 1.04 & $1.02 ; 1.06$ & $<0.001$ & $<0.001$ \\
\hline $\begin{array}{l}\text { Herd average number of lactations } \\
\text { (years) (centered) }\end{array}$ & & & 0.49 & $0.42 ; 0.57$ & $<0.001$ & $<0.001$ \\
\hline $\begin{array}{l}\text { Square term centered value of herd } \\
\text { average number of lactations (years) }\end{array}$ & & & 1.11 & $1.06 ; 1.17$ & $<0.001$ & $<0.001$ \\
\hline \multirow[t]{4}{*}{ Region ${ }^{\mathrm{a}, \mathrm{d}}$} & North-East & 43,015 & 1 & & & $<0.001$ \\
\hline & South-East & 23,039 & 0.82 & $0.73 ; 0.93$ & 0.001 & \\
\hline & South-West & 25,206 & 0.82 & $0.74 ; 0.90$ & $<0.001$ & \\
\hline & North-West & 16,575 & 0.90 & $0.81 ; 1.01$ & 0.076 & \\
\hline
\end{tabular}

Shape parameter $p=0.83$

a number of animals in each category

${ }^{b}$ number of observations

cnumber of observations in each category after splitting the observations at 7th day post-calving

${ }^{\mathrm{d}}$ Northeast Estonia: Ida-Viru, Lääne-Viru, Jõgeva, Järva county; Southeast Estonia: Tartu, Valga, Võru, Põlva county; Southwest Estonia: Pärnu, Viljandi, Saare county; Northwest Estonia: Harju, Rapla, Lääne, Hiiu county

representative data. Care is needed when interpreting this data due to somewhat overlapping categories. Some cows might also have more than one reason for culling, whereas the ELPR system allows farmers to mark only one reason for each culling event. Also, the stated culling reasons might be the consequences of the primary disorder that might differ from what was reported by the farmers. Therefore these results are rather indicative and further studies including necropsy, meat inspection and laboratory data together with animal and disease history could reveal more reliable results. The four most common reasons for culling due to death and slaughter were: "feet/claw disorders", "udder disorders", "metabolic and digestive disorders", and "fertility problems", the order of frequency being broadly similar to those described by other authors [24]. The proportion of "feet/claw disorders" as the reason of culling was somewhat more prevalent compared to what was reported in studies performed in other European countries [6, 25]. As small herds with less than 20 cow-years were excluded in this study and majority of the Estonian dairy cows were housed in large herds [26], the conditions of large dairy herds and their effect on the cow hoof health were probably over-represented in the present study compared to other studies. In large Estonian dairy farms, cows are mostly housed in freestalls, and the latter is shown to be associated with an increased risk for lameness relative to other housing systems, including tie stalls and straw yards [27]. Additionally, other factors accompanying freestalls such as prolonged standing time due to milking [28], overstocking [29] or poor stall design [28] can increase the risk of lameness.

Metabolic disorders were a more common reason for culling in multiparous compared to primiparous cows. Roberts et al. [30] concluded that primiparous cows may have a different physiological response to post-calving metabolic challenges. The need to balance between energy demands for growth and milk production may have an effect on more effective fat mobilization before health and productivity are compromised [30].

A minor increase in the culling hazard occurred about a year after calving. As fertility problems were the 
Table 5 Results of multivariable random-effect Weibull model for risk factors for culling due to slaughter and death in 232,445 lactations of 140,934 dairy cows (herds $n=410$ )

\begin{tabular}{|c|c|c|c|c|}
\hline Variable & Category & $N^{a, b}$ & Hazard Rate Ratio & 95\% Confidence Intervals \\
\hline \multicolumn{5}{|l|}{ Animal-level variables } \\
\hline Days in milk at first test-milking (centered) & & & 1.008 & $1.007 ; 1.009$ \\
\hline $\begin{array}{l}\text { Square term of days in milk at first test- } \\
\text { milking (centered) }\end{array}$ & & & 0.9997 & $0.9995 ; 0.9997$ \\
\hline Milk yield at first test-milking (centered) (kg) & & & 0.96 & $0.956 ; 0.958$ \\
\hline $\begin{array}{l}\text { Square term of milk yield at first test- } \\
\text { milking (centered) }\end{array}$ & & & 1.001 & $1.0011 ; 1.0013$ \\
\hline \multirow[t]{2}{*}{ Milk fat/protein ratio at first test-milking ${ }^{b}$} & $<1.5$ & 181,507 & 1 & \\
\hline & $\geq 1.5$ & 50,938 & 1.23 & $1.20 ; 1.26$ \\
\hline \multirow{2}{*}{$\begin{array}{l}\text { Milk somatic cell count at first test- } \\
\text { milking }\left({ }^{*} 1000 / \mathrm{mL}\right)^{\mathrm{b}}\end{array}$} & $<200$ & 174,387 & 1 & \\
\hline & $\geq 200$ & 58,058 & 1.31 & $1.28 ; 1.34$ \\
\hline \multirow[t]{3}{*}{ Milking method at first test-milking ${ }^{b}$} & Milking twice a day & 163,033 & 1 & \\
\hline & Milking three times a day & 41,773 & 0.79 & $0.74 ; 0.84$ \\
\hline & Robot milking & 27,639 & 0.57 & $0.53 ; 0.61$ \\
\hline \multirow[t]{2}{*}{ Breed $^{a}$} & Estonian Holstein & 113,284 & 1 & \\
\hline & Estonian Red and Estonian Native & 27,650 & 0.79 & $0.76 ; 0.82$ \\
\hline \multirow[t]{7}{*}{ Parity ${ }^{b}$} & First & 77,456 & 1 & \\
\hline & Second & 60,689 & 2.09 & $2.03 ; 2.16$ \\
\hline & Third & 41,267 & 2.89 & $2.79 ; 2.99$ \\
\hline & Fourth & 25,810 & 3.65 & $3.52 ; 3.78$ \\
\hline & Fifth & 14,398 & 4.35 & $4.18 ; 4.53$ \\
\hline & Sixth & 7334 & 4.96 & $4.72 ; 5.21$ \\
\hline & $\geq$ Seventh & 5491 & 6.12 & $5.80 ; 6.45$ \\
\hline \multirow[t]{3}{*}{ Calving year } & 2013 & 77,968 & 1 & \\
\hline & 2014 & 81,011 & 0.996 & $0.97 ; 1.02$ \\
\hline & 2015 & 73,466 & 0.95 & $0.92 ; 0.97$ \\
\hline \multicolumn{5}{|l|}{ Herd-level variables } \\
\hline $\begin{array}{l}\text { Herd average number of cows } \\
\text { (one unit change is } 50 \text { cows) }\end{array}$ & & & 1.01 & $1.001 ; 1.03$ \\
\hline $\begin{array}{l}\text { Herd average milk yield (one unit } \\
\text { change is } 500 \mathrm{~kg} \text { ) }\end{array}$ & & & 1.15 & $1.13 ; 1.17$ \\
\hline \multirow[t]{4}{*}{ Region $^{\mathrm{a}, \mathrm{d}}$} & Northeast & 117 & 1 & \\
\hline & Southeast & 98 & 0.87 & $0.76 ; 0.9993$ \\
\hline & Southwest & 121 & 0.90 & $0.90 ; 1.003$ \\
\hline & Northwest & 74 & 0.90 & $0.80 ; 1.02$ \\
\hline \multirow[t]{5}{*}{ Change of herd size from 2013 to $2015^{c}$} & No change $( \pm 5 \%)$ & 135 & 1 & \\
\hline & Decrease $>5$ to $15 \%$ & 71 & 1.03 & $0.86 ; 1.23$ \\
\hline & Decrease $>15 \%$ & 68 & 1.48 & $1.24 ; 1.77$ \\
\hline & Increase $>5$ to $15 \%$ & 74 & 0.89 & $0.74 ; 1.06$ \\
\hline & Increase > 15\% & 62 & 0.86 & $0.71 ; 1.03$ \\
\hline
\end{tabular}

Shape parameter $p=1.09$

${ }^{a}$ number of cows in each category

${ }^{b}$ number of observations in each category

c number of herds in each category

${ }^{\mathrm{d}}$ Northeast Estonia: Ida-Viru, Lääne-Viru, Jõgeva, Järva county; Southeast Estonia: Tartu, Valga, Võru, Põlva county; Southwest Estonia: Pärnu, Viljandi, Saare county; Northwest Estonia: Harju, Rapla, Lääne, Hiiu county 
primary reason for culling in the late lactation stage ( $\geq 200$ DAC), we might assume that at that time farmers mostly cull their non-pregnant cows. Cows sent for slaughter should not be in their last trimester of pregnancy, according to a Motion for a European Parliament resolution [31]. The Estonian milk recording register system allows farmers to report only one reason for each culling event. Therefore it might be possible that some proportion of cows that were culled due to other reasons than fertility during the last third of lactation were also non-pregnant due to suffering from chronic health disorders or according to the farmers' decisions.

Loss of a cow at its first lactation is economically most devastating and therefore undesirable for the dairy farmer [1]. In order to lower the culling rate of primiparous cows, measures promoting the good health of feet and udder are of utmost importance. In primiparous cows, dystocia and low milk yield both constituted roughly $9 \%$ of all culling reasons during the first 100 DAC, being nearly twice as high as that reported in multiparous cows. According to Mee [32], the fetopelvic disproportion is the predominating risk factor for dystocia in primiparous cows, therefore bull selection as well as heifer nutrition and development might be critical factors lowering dystocia that leads to culling in primiparous cows.

We also identified some differences in culling reasons over lactations. Fertility, as a reason for culling, decreased in importance with each parity, indicating that probably more resilient cows in terms of breeding capability remained in the herds. Metabolic and digestive disorders as well as udder disorders were more frequently stated as the reason for culling in older cows. The fact that each calving event cumulatively adds the risk of suffering postpartum diseases, such as mastitis and ketosis [33, 34], might also explain this identified association.

\section{Animal-level risk factors for culling}

In the current study, several common risk factors for culling in primiparous and multiparous cows were identified. Holstein breed cows had a significantly higher culling hazard compared to Estonian Red and Estonian Native breed cows. Holstein breed cows have a higher milk yield in Estonia [11]. Concomitantly, pure Holstein breed cows are more susceptible to production-related diseases [35] and have poorer reproductive performance than crossbred cows [36], thus being more prone to culling.

We identified that higher individual milk yield breeding value was a protective factor for culling, which may be explained by farmers trying to keep cows with good genetic merit. A milk yield breeding value could be calculated for cows who have at least two test-milking results available and whose sire has obtained a milk yield breeding value. The category "missing" also included cows that were culled during early lactation, which might be the cause of high culling hazard among primiparous cows who had no breeding value in the dataset.

In agreement with other studies, it is essential to pay attention to predisposing conditions and transmission of infectious diseases that might be associated with the incidence of stillbirth or abortion, as these are important risk factors for cow culling and longevity [37, 38]. Additionally, higher culling risk due to giving birth to a male calf compared to a female calf indicates that birth weight of an offspring might be an important factor in terms of culling via increasing the probability for dystocia. This is known to be associated with a higher mortality hazard in cows [33] as well as an increased risk of post-partum diseases eventually leading to culling [39]. Furthermore, calving for the first time at a higher age was associated with a higher culling hazard. Interestingly, the association was also present in multiparous cows, suggesting a possible long-term impact. Heifers might calve at an older age due to management factors, health disorders, feeding management, or due to herd breeding strategies [23, 40], and the reason for the old age at first calving may be more important for the culling risk than the age per se.

In multiparous cows, a longer previous calving interval was associated with a higher culling probability at next lactation. Prolonged calving interval might be related to negative energy balance and diseases associated with the early post-partum period, delaying conception. Due to the possible recurrent propensity of post-partum diseases at the cow level, the undesired impact of a longer calving interval might manifest at the next lactation. In addition, a longer calving interval allows cows to gain more weight, which may be a risk factor for developing post-partum diseases, increasing the culling hazard [41].

High somatic cell count at last test-milking during the previous lactation and/or at first test-milking after calving, indicating the presence of subclinical intramammary infection, was a factor associated with higher culling risk during lactation. The presence of clinical or subclinical mastitis is a known risk factor for dairy cow culling [39]. Lower milk yield at the end of the previous lactation or at the first testmilking of ongoing lactation was also associated with a higher culling probability. It has been shown that, in general, farmers are more eager to cull lowproducing cows [39]. Still, low milk yield soon after calving might be associated with an underlying disease. The high milk fat/protein ratio is a valuable indicator of ketosis in the early post-partum period [42], and it is concomitantly related to increased probabilities of developing displaced abomasum, retained placenta, metritis, clinical endometritis and 
clinical ketosis as well as higher culling probabilities $[43,44]$.

\section{Herd-level factors associated with culling}

On average, the cow culling hazard was higher in larger herds. The association between herd size and the health and welfare of dairy cows is complex and includes the impact of several factors, including facilities, management and operational factors [20,45]. According to previous studies, the positive association between the incidence of metabolic diseases and herd size have been found [46]. Also, the presence and dynamics of infectious diseases and different biosecurity management could explain higher culling risk in larger herds [23]. According to Gieseke and co-authors [47], housing conditions and management practices have a greater effect on cow welfare than the herd size itself and more research is needed to identify factors in large farms that affect animal health. Simultaneously to the European Union, the milk price dropped suddenly in the autumn of 2014 in Estonia [48], resulting in a 5.2 and $11 \%$ reduction of the number of dairy cows and herds, respectively, in Estonia during the year of 2015 [49]. Due to this, change of herd size was controlled as a factor in the statistical models to account for its confounding effect.

Higher herd average milk yield was associated with increased culling hazard of individual cows in our study. Several previous studies have found that higher milk yield has an adverse effect on the cows' resistance to diseases, as it is correlated with presence of the clinical mastitis, reproductive diseases [50], and other postpartum disorders [43]. Although high milk yield and the high genetic potential for milk production are often been blamed for the short longevity of dairy cows, this does not always seem to affect cow longevity [51]. On the other hand, due to uncertain causality, herds with higher milk yield might also have better reproductive performance, allowing more cows to be culled.

The current study showed that herds with a longer average calving interval had a lower risk of culling. A longer calving interval may be the consequence of fertility problems in the herd or the result of a voluntary decision of the farmer to delay with breeding after calving and thus to extend the lactation period [52]. Although a shorter calving interval is considered as economically optimal [53], an economic benefit in extending lactations in high-yielding cows was also found [54]. In the study by Allore and Erb [55], a lower risk of culling for reproductive failure was present in herds with an extended voluntary waiting period. Still, due to a cross-sectional study design, it is impossible to draw causal inferences, and the identified association might result from farm lower thresholds for culling non-pregnant cows [39].
In the current study, the cow culling hazard was also negatively associated with herd average lactation number that cumulatively aggregates the individual animal culling hazards.

Using robot milking system was a protective factor for culling compared to other milking methods. Additionally, cows that were milked three times a day at first test-milking had a lower culling probability throughout the lactation compared to cows that were milked twice a day. Farms with automatic milking systems differ from those with other milking systems in many aspects, such as environmental conditions, feeding management, grouping policies, etc. Unfortunately, it was not possible to discriminate milking method, but only the milking frequency, meaning that the identified associations could be affected by other factors.

\section{Validity and limitations of the study}

The present study included lactation-level records of all cows from all herds that had at least 20 cow-years in years 2013-2015 in Estonia and participated in the milk recording system. According to the ELPR [26], 94.1\% (in 2013) to $95.4 \%$ (in years 2014 and 2015) of the Estonian dairy cow population was enrolled in the milk recording system, probably leaving out smaller farms that produced milk for their own consumption. After skipping herds with $<20$ cow-years, we emphasize a good external validity of this study for medium or large sized herds, whereas the study results should not be extrapolated to small dairy holdings.

When analysing farmers' reported reasons for culling, a reporting bias might be present. In Estonia, farmers are allowed to report only one reason for each animal exit to the milk recording register. Still, studies have shown that in many instances, farmers report more than one reason of culling when allowed [56, 57]. To our knowledge, there are no studies that investigate the farmers' behaviour in reporting culling reasons. We assume that farmers report the main and most obvious reason of culling at the time the cow is leaving the herd. However, this might not be the primary or ultimate disease or disorder which leads to culling.

In the EU, there is a harmonized mandatory registration and reporting of animal births, movements, and deaths [58] making registry data reliable for research purposes. As participation in the milk recording register is voluntary, the reporting in that system might not always be precise. Although the animal registry and milk recording registry makes crosschecks in their data, small discrepancies were found when comparing the cows' exit dates in the two registries. Also, some cows had very long lactations and low number of culls occurred far away from the latest calving (Fig. 2) in which a new calving date might have remained unreported in the 
registry. Still, due to the high sample size of this study, these aberrations probably have no effect on the overall results and conclusions.

\section{Conclusions}

Culling rates of Estonian dairy cows housed in farms with more than 20 cows were comparable to that reported in other countries. More attention should be paid to prevention of feet/claw disorders and mastitis, because they accounted for roughly half of the reported culling reasons. The early post-partum period was the period bearing the highest risk for cow culling, with metabolic diseases and feet/claw diseases being the most frequently stated reasons for culling at that time. Our analyses confirmed the importance of easy calving and ensuring good health around calving to avoid the loss of a cow. Due to the intensification of dairy production and the identified higher culling hazards in larger herds, further studies should concentrate on factors that contribute to cow culling and longevity in large commercial herds. Along these same lines, a widened list of herd factors, including animal housing, environment, management as well as farm workers' attitude and motivation, should be studied helping to understand the complex problem of cow culling and combat the problem of reduced cow longevity.

\section{Methods}

\section{Datasets}

All data used for the present study was based on recordings in the Estonian Farm Animal Register kept by the Estonian Agricultural Registers and Information Board and data of Estonian Livestock Performance Recording Ltd. (ELPR, national voluntary animal production system involved with monthly test-milkings including data of around 95\% of dairy cows in Estonia, called "milk recording register" hereafter). Cow lactation level records for the period between January 1, 2013 and December 31, 2015 were collected from the milk recording register. Data was required of all Estonian dairy herds that participated in the milk recording register and had a herd size of at least 20 cows at the start of the study period. The initial datasets included lactation level data of 86,459 primiparous and 109,314 multiparous cows $(177,712$ lactations) from 409 and 410 dairy herds, respectively.

The lactation level observation period started at the day of calving and ended at the date the cow left the herd, had a new calving, or up to the end of the study period (December 31, 2015). Due to the aim of reducing the impact of voluntary culling in the analysis, the definition "culling" established by [1] was modified in the sense that sold cows (cows that were sold to another farm for productive life) were considered as right censored observations, thus excluding sales from the culling definition. Therefore the definition of culling in this study includes on-farm mortality (unassisted death and euthanasia) and slaughter (sending cows to an abattoir).

Farmers are obliged to report all movements and exits of cattle to the Estonian Farm Animal Register within 7 days [59]. In the Farm Animal Register, it is specified for each exit event whether the animal died on-farm, was euthanized, got lost, was slaughtered or was sold/ exported. Farmers report the reason of exit in the milk recording register, choosing one reason from the list of 24 pre-defined categories, including selling, old age, low milk yield, mastitis, metabolic disorders, abortion, etc. (the complete list is given below in the section "Data editing"). The definition of these categories was not provided to the farmers by the registry. In order to analyse the proportion of deaths (including euthanasia) and slaughter as well as include a reason for each exit event, the data of two registries was merged by cow identification numbers. Due to the fact that the analyzed datasets were on a lactation level and Farm Animal Register data on cow level and one animal might have more than one exit during its lifetime (e.g., sold and slaughtered/died), the exit dates of the two datasets were compared in order to connect a correct exit type (death / euthanasia / selling / slaughter) and farmers' stated reason for animal exit. Reporting reasons of cattle exit in the milk recording register by farmers is voluntary, therefore it was expected that the dates of cattle exit in two datasets would slightly differ. When joining the datasets of two registries, differences of exit dates up to seven days were allowed and were considered to be the same exit event.

The data from Farm Animal Register consisted of farm identification number together with the owner's name, location of a herd, animal identification number, birth date, sex and breed of an animal, exit date and type of exit. Milk recording register data included animal, lactation and herd level data. A more detailed description of the data provided in the milk recording system is described in [60].

\section{Data editing}

Due to inexplicable short calving intervals (calving interval $<290$ days and no stated abortion or stillbirth in the registry), 86 and 151 lactation records were removed from the datasets of primiparous and multiparous cows, respectively.

Ten categories of culling reasons were created by compiling together similar culling reasons available in ELPR system. Farmers' stated reasons for culling due to death and slaughter were categorized as follows:

- feet and claw disorders: included pre-defined categories "undesirable leg conformation", "leg traumas" and "leg disorders"; 
- respiratory and infectious diseases: "respiratory diseases" and "infectious diseases";

- metabolic and digestive disorders: "metabolic disorders", "milk fever" and "gastrointestinal disorders";

- fertility problems: "fertility problems", "gynecological diseases", "abortion";

- dystocia;

- trauma and accident: "other traumas" and "accident";

- udder disorders: "udder flaws", "udder and teat traumas" and "mastitis";

- low milk yield;

- age;

- other reasons: "animal lost", "bad temperament", "bad milking", "selling" and "other reasons".

The category "other reasons" included farmers' stated reasons that were rarely reported or not reasonably associated with death and slaughter, thus considered to be recording mistakes. In order to determine whether the cow was purchased or not, the birth farm identification number was compared with the farm number in which the cow was located. Milk yield breeding value was not available for all cows (in case the sire of a cow had not received a milk yield breeding value or the cow had less than two test milking results available), thus the variable was categorised into roughly equally sized groups with a separate category for cows with missing information. Due to a low number of Estonian Native breed cows, these observations were merged with Estonian Red breed cows. Counties were combined into four regions: Northeast, Southeast, Southwest, and Northwest regions. Four seasons were created based on the calving dates of the cows: winter (December-February), spring (March-May), summer (June-August) and autumn (September-November). The variable "change of herd size" was created by comparing the number of cows in the herd between 2013 to 2015. Based on that, five categories were created: no considerable change in the number of cows $( \pm 5 \%)$, decrease $>5$ to $15 \%$, decrease $>15 \%$, increase $>5$ to $15 \%$ and increase $>15 \%$.

Data related with test-milkings was categorized when a biological threshold for discriminating normal from pathological conditions was available. The variable "milk somatic cell count" had two categories separated at the level of 200,000 cells/ml [61]. A threshold of 1.5 was used to dichotomise "milk fat/protein ratio" [43] and 6.78 $\mathrm{mmol} / \mathrm{L}$ was the limit value for "milk urea content" [62].

For the herd-level production and reproduction data, three-year averages were calculated (Supplementary Table 1A).

\section{Data analysis}

A descriptive statistical data analysis was performed to identify farmers' stated reasons for culling. The analysis was performed separately per parity as well as by stage of lactation.

Risk factor analysis for cow culling (on-farm death, euthanasia or slaughter) was performed separately for primiparous and multiparous cows due to different sets of variables used. A complete description of the statistical methods used can be found in [60]. Briefly explained, the Weibull proportional hazard regression model specifying herd as a random factor (gamma distributed frailty effect) was applied specifying culling as a failure event. Lactation level observation period started at the day of calving or at the day of purchase of a lactating cow. In order to account for the left truncation in the analyses [63] the "start date" was accounted as January 1, 2013 for observations that started before that date by specifying the "stset" options in STATA MP 14 software (StataCorp LP, College Station, USA). Observations that ended with new calving, selling, or the end of the study period were right censored. Due to several lactations of multiparous cows in the dataset during a study period, the animal identification number was specified as the multiple-record ID variable when setting time-toevent data. A Kaplan-Meier survival curve was created to compare the survival probability of primiparous and multiparous cows over lactation by plotting estimates survival curves. Culling rates together with $95 \%$ confidence intervals were calculated by using the MantelHaenszel method. Estimated cumulative survivor hazard function was calculated to describe the culling probabilities at different time-points over lactation. In order to identify the difference of culling hazards between primiparous and multiparous cows, a univariable proportional hazard Weibull regression model was composed including cow parity (primiparous / multiparous) as a fixed effect and herd as a frailty term.

After univariable screening of the predictors in their association with culling probability all variables with a liberal $p$-value of $<0.05$ and not collinear to each other were considered as candidates in multivariable analysis. A multivariable Weibull model was built by removing insignificant predictor variables from the model by manual backward elimination technique. Due to the variable "Assisted calving" having a time-dependent effect, the lactation-level observation period was split on the seventh day post-calving using the 'stsplit' command. Due to the high power of the analyses coming from a large sample size, the predictor variables included in the final model had to be associated with the culling hazard at a $1 \%$ significance level.

Due to differences in the beginning of the observation period, a separate model was conducted to analyse the associations between first test-milking results and culling during lactation controlling for confounding variables ("days in milk", "breed", "parity", "calving year", "herd 
average number of cows" and "change of herd size from 2013 to 2015") in the model. In that model, the observation period started from the day of the first test-milking and lasted until culling (failure event), right censoring due to new calving, selling of an animal or the end of the study period. The model included the data of primiparous and multiparous cows.

Akaike's and Bayesian Information Criteria (AIC and BIC, respectively) values were used for comparing models, and lower AIC/BIC values determined the better model. Plots of the cumulative hazard versus Cox-Snell residuals were generated to assess the model fit. Proportional hazard assumption was evaluated by graphical assessment of log-cumulative hazard plots [64]. Statistical analyses were performed using STATA MP version 14 (StataCorp LP, College Station, USA).

\section{Supplementary information}

Supplementary information accompanies this paper at https://doi.org/10. 1186/s12917-020-02384-6.

Additional file 1 Supplementary Table 1A. Descriptive statistics of potential continuous risk factors for culling of 86,373 primiparous and 109,295 multiparous dairy cows with 177,561 lactations in Estonia between January 1, 2013 and December 31, 2015.

Additional file $\mathbf{2}$ Supplementary Table 1B. Descriptive statistics of potential categorical risk factors for culling of 86,373 primiparous and 109,295 multiparous dairy cows with 177,561 lactations in Estonia between January 1, 2013 and December 31, 2015.

\section{Abbreviations}

CR: Culling rate; HR: Hazard rate; DAC: Days after calving; SCC: Somatic cell count; ELPR: Estonian Livestock Performance Recording Ltd.; AIC: Akaike's Information Criteria; BIC: Bayesian Information Criteria

\section{Acknowledgements}

The authors thank Olle Antson (Estonian Agricultural Registers and Information Board) and Inno Maasikas (Estonian Livestock Performance Recording Ltd) for data inquiry.

\section{Authors' contributions}

KM conceived the research grant. TR, KM, KR, TO, UE and AV designed the study, TR, KM and KR arranged the databases. TR and KM performed the statistical analyses and interpreted the study results. All authors were involved in drafting the manuscript and approved the final submitted version of the manuscript.

\section{Funding}

This project was funded by the Estonian Research Council grant (PSG268) The funding body had no role in the design of the study and collection, analysis, and interpretation of data and in writing the manuscript.

\section{Availability of data and materials}

Access to data used in present study was provided by the Estonian Farm Animal Register kept by the Estonian Agricultural Registers and Information Board and Estonian Livestock Performance Recording Ltd., according to agreement. Restrictions apply to the availability of these data and so are not publicly available.

\section{Ethics approval and consent to participate}

Permission to analyse the data and publish the study results was given by the Estonian Agricultural Registers and Information Board and Estonian Livestock Performance Recording Ltd. by providing the data in response to written statement explaining the purpose of the study, process of data handling and publication of the study results.

\section{Consent for publication}

Not applicable.

\section{Competing interests}

The authors declare that they have no competing interests.

\section{Author details}

${ }^{1}$ Institute of Veterinary Medicine and Animal Sciences, Estonian University of Life Science, Kreutzwaldi 62, 51006 Tartu, Estonia. ${ }^{2}$ Department of Clinical Sciences, Swedish University of Agricultural Sciences, SE-75007 Uppsala, Sweden.

Received: 20 January 2020 Accepted: 19 May 2020

Published online: 01 June 2020

\section{References}

1. Fetrow J, Nordlund KV, Norman HD. Invited review: Culling: Nomenclature, definitions, and recommendations. J Dairy Sci. 2006;89(6):1896-905. https:// doi.org/10.3168/jds.S0022-0302(06)72257-3.

2. Rogers GW, Van Arendonk JAM, McDaniel BT. Influence of Production and Prices on Optimum Culling Rates and Annualized Net Revenue. J Dairy Sci. 1988;71(12):3453-62. https://doi.org/10.3168/jds.S0022-0302(88)79951-8.

3. Hadley GL, Wolf CA, Harsh SB. Dairy cattle culling patterns, explanations, and implications. J Dairy Sci. 2006;89(6):2286-96. https://doi.org/10.3168/jds. S0022-0302(06)72300-1.

4. Weigel KA, Palmer RW, Caraviello DZ. Investigation of factors affecting voluntary and involuntary culling in expanding dairy herds in Wisconsin using survival analysis. J Dairy Sci. 2003;86(4):1482-6. https://doi.org/10. 3168/jds.S0022-0302(03)73733-3.

5. Dürr JW, Monardes HG, Cue RI, Philpot JC. Culling in Quebec Holstein herds. 1. Study of phenotypic trends in herd life. Can J Anim Sci. 1997;77(4):593600. https://doi.org/10.4141/A96-131.

6. Ahlman T, Berglund B, Rydhmer L, Strandberg E. Culling reasons in organic and conventional dairy herds and genotype by environment interaction for longevity. J Dairy Sci. 2011;94(3):1568-75. https://doi.org/10.3168/jds.20103483.

7. De Vries M, Bokkers EA, Dijkstra T, Van Schaik G, De Boer IJ. Invited review: associations between variables of routine herd data and dairy cattle welfare indicators. J Dairy Sci. 2011;94(7):3213-28 10.3168/jds.2011-4169.

8. Bell MJ, Wall E, Russell G, Roberts DJ, Simm G. Risk factors for culling in Holstein-Friesian dairy cows. Vet Rec. 2010;167(7):238-40. https://doi.org/10. 1136/vr.c4267

9. Compton CWR, Heuer C, Thomsen PT, Carpenter TE, Phyn CVC, McDougall S. Invited review: a systematic literature review and meta-analysis of mortality and culling in dairy cattle. J Dairy Sci. 2017 Oct 27;100(1):1-16. https://doi.org/10.3168/jds.2016-11302.

10. EARIB. Estonian Livestock Performance Recording Yearbook. 2017. Jõudluskontrolli aastaraamat 2017 (in Estonian). 2017. https://www.epj.ee/ assets/tekstid/aastaraamatud/aastaraamat_2017.pdf.

11. EARIB. Estonian Livestock Performance Recording Yearbook. 2018. Jõudluskontrolli aastaraamat 2018 (in Estonian). 2018. https://www.epj.ee/ assets/tekstid/aastaraamatud/aastaraamat_2018.pdf.

12. Brickell JS, Wathes DC. A descriptive study of the survival of HolsteinFriesian heifers through to third calving on English dairy farms. J Dairy Sci. 2011;94(4):1831-8. https://doi.org/10.3168/jds.2010-3710.

13. Archer SC, Mc Coy F, Wapenaar W, Green MJ. Association between somatic cell count early in the first lactation and the longevity of Irish dairy cows. J Dairy Sci. 2013;96(5):2939-50. https://doi.org/10.3168/jds.2012-6115.

14. Stevenson MA, Lean IJ. Risk factors for culling and deaths in eight dairy herds. Aust Vet J. 1998;76(7):489-94. https://doi.org/10.1111/j.1751-0813. 1998.tb10190.x

15. Bach A. Associations between several aspects of heifer development and dairy cow survivability to second lactation. J Dairy Sci. 2011;94(2):1052-7. https://doi.org/10.3168/jds.2010-3633.

16. Clark B, Stewart GB, Panzone LA, Kyriazakis I, Frewer LJ. A systematic review of public attitudes, perceptions and Behaviours towards production diseases associated with farm animal welfare. J Agric Environ Ethics. 2016;29(3):45578. https://doi.org/10.1007/s10806-016-9615-x. 
17. Raaperi K, Bougeard S, Aleksejev A, Orro T, Viltrop A. Association of herd BRSV and BHV-1 seroprevalence with respiratory disease and reproductive performance in adult dairy cattle. Acta Vet Scand. 2012;30, 54(1). https://doi. org/10.1186/1751-0147-54-4

18. Wäänänen JE. Cure rate of cows with digital dermatitis in one Estonian dairy herd. (Master's thesis, Estonian University of Life Science). 2019. http:// hdl.handle.net/10492/4871.

19. Timonen AAE, Katholm J, Petersen A, Mõtus K, Kalmus P. Within-herd prevalence of intramammary infection caused by mycoplasma bovis and associations between cow udder health, milk yield, and composition. J Dairy Sci. 2017;100(8):6554-61. https://doi.org/10.3168/jds.2016-12267.

20. Barkema HW, von Keyserlingk MAG, Kastelic JP, Lam TJGM, Luby C, Roy JP, et al. Invited review: changes in the dairy industry affecting dairy cattle health and welfare. J Dairy Sci. 2015;98(11):7426-45. https://doi.org/10.3168/ jds.2015-9377.

21. Dechow CD, Goodling RC. Mortality, culling by sixty days in milk, and production profiles in high- and low-survival Pennsylvania herds. J Dairy Sci. 2008;91(12):4630-9. https://doi.org/10.3168/jds.2008-1337.

22. Haine D, Delgado H, Cue R, Sewalem A, Wade K, Lacroix R, et al. Culling from the herd's perspective-exploring herd-level management factors and culling rates in Québec dairy herds. Prev Vet Med. 2017 Nov 1;147:132-41. https://doi.org/10.1016/j.prevetmed.2017.08.020.

23. Nor NM, Steeneveld W, Hogeveen $\mathrm{H}$. The average culling rate of Dutch dairy herds over the years 2007 to 2010 and its association with herd reproduction, performance and health. J Dairy Res. 2014;81(1):1-8. https:// doi.org/10.1017/S0022029913000460.

24. Orpin PG, Esslemont RJ. Culling and wastage in dairy herds: an update on incidence and economic impact in dairy herds in the UK. Cattle Pract. 2010; 18(3):163-72 https://www.researchgate.net/profile/Peter_Orpin2/ publication/285958912

25. Heise J, Liu Z, Stock KF, Rensing S, Reinhardt F, Simianer H. The genetic structure of longevity in dairy cows. J Dairy Sci. 2016;99(2):1253-65. https:// doi.org/10.3168/jds.2015-10163.

26. EARIB. Estonian Livestock Performance Recording Yearbook. 2015. Jõudluskontrolli aastaraamat 2015 (in Estonian). 2015. https://www.epj.ee/ assets/tekstid/aastaraamatud/aastaraamat_2015.pdf.

27. Cook NB. Prevalence of lameness among dairy cattle in Wisconsin as a function of housing type and stall surface. J Am Vet Med Assoc 2003;223(9): 1324-1328. doi: 10.2460/javma.2003.223.1324.

28. Espejo LA, Endres MI. Herd-level risk factors for lameness in high-producing Holstein cows housed in freestall barns. J Dairy Sci. 2007;90(1):306-14. https://doi.org/10.3168/jds.S0022-0302(07)72631-0.

29. Fregonesi JA, Tucker CB, Weary DM. Overstocking reduces lying time in dairy cows. J Dairy Sci. 2007;90(7):3349-54. https://doi.org/10.3168/jds. 2006-794.

30. Roberts T, Chapinal N, LeBlanc SJ, Kelton DF, Dubuc J, Duffield TF. Metabolic parameters in transition cows as indicators for early-lactation culling risk. J Dairy Sci. 2012;95(6):3057-63. https://doi.org/10.3168/jds.2011-4937.

31. EU Publications Office. Motion for a European Parliament resolution on monitoring the slaughter of pregnant cows B8-0033/2017. 2009. http:// www.europarl.europa.eu/doceo/document/B-8-2017-0033_EN.html.

32. Mee JF. Prevalence and risk factors for dystocia in dairy cattle: a review. Vet J. 2008;176(1):93-101. https://doi.org/10.1016/j.tvjl.2007.12.032

33. Alvåsen $K$, Jansson Mörk M, Dohoo IR, Sandgren $C H$, Thomsen PT, Emanuelson U. Risk factors associated with on-farm mortality in Swedish dairy cows. Prev Vet Med. 2014;117(1):110-20. https://doi.org/10.1016/j. prevetmed.2014.08.011.

34. Goto A, Takahara K, Sugiura T, Oikawa S, Katamato H, Nakada K. Association of postpartum diseases occurring within 60 days after calving with productivity and reproductive performance in dairy cows in Fukuoka: a cow-level, retrospective cohort study. J Vet Med Sci. 2019;81(7):1055-62. https://doi.org/10.1292/jvms.18-0384.

35. Mee JF. Managing the dairy cow at calving time. Vet Clin Food Anim. 2004; 20(3):521-46. https://doi.org/10.1016/j.cvfa.2004.06.001.

36. Heins BJ, Hansen LB, Seykora AJ. Fertility and survival of pure Holsteins versus crossbreds of Holstein with Normande, Montbeliarde, Scandinavian red. J Dairy Sci. 2006;89(12):4944-51. https://doi.org/10.3168/jds.S00220302(06)72545-0.

37. Bicalho RC, Galvão KN, Cheong SH, Gilbert RO, Warnick LD, Guard CL. Effect of stillbirths on dam survival and reproduction performance in Holstein dairy cows. J Dairy Sci. 2007;90(6):2797-803. https://doi.org/10.3168/jds. 2006-504.

38. Sewalen A, Miglior F, Kistemaker GJ, Sullivan P, Van Doormaal BJ. Relationship between reproduction traits and functional longevity in Canadian dairy cattle. J Dairy Sci. 2008;91(4):1660-8. https://doi.org/10.3168/ jds.2007-0178.

39. Rajala-Schultz PJ, Gröhn YT. Culling of dairy cows. Part III. Effects of diseases, pregnancy status and milk yield on culling in Finnish Ayrshire cows. Prev Vet Med. 1999;41(4):295-309. https://doi.org/10.1016/S0167-5877(99)00047-1.

40. Davis Rincker LE, VandeHaar MJ, Wolf CA, Liesman JS, Chapin LT, Weber Nielsen MS. Effect of intensified feeding of heifer calves on growth, pubertal age, calving age, milk yield, and economics. J Dairy Sci. 2011;94(7):3554-67. https://doi.org/10.3168/jds.2010-3923.

41. Stevenson JS. Reproductive Management of Dairy Cows in High MilkProducing Herds. J Dairy Sci. 2001;84:E128-43. https://doi.org/10.3168/jds. S0022-0302(01)70207-X.

42. Duffield TF, Kelton DF, Leslie KE, Lissemore KD, Lumsden JH. Use of test day milkfat and milk protein to detect subclinical ketosis in dairy cattle in Ontario. Can VetJ. 1997;38(11):713-8 PMCID: PMC1576823 PMID: 9360791.

43. Heuer C, Schukken YH, Dobbelaar P. Postpartum body condition score and results from the first test day milk as predictors of disease, fertility, yield, and culling in commercial dairy herds. J Dairy Sci. 1999;82(2):295-304. https:// doi.org/10.3168/jds.S0022-0302(99)75236-7.

44. Toni F, Vincenti L, Grigoletto L, Ricci A, Schukken YH. Early lactation ratio of fat and protein percentage in milk is associated with health, milk production, and survival. J Dairy Sci. 2011;94(4):1772-83. https://doi.org/10. 3168/jds.2010-3389.

45. Evink TL, Endres MI. Management, operational, animal health, and economic characteristics of large dairy herds in 4 states in the upper Midwest of the United States. J Dairy Sci. 2017;100(11):9466-75. https://doi.org/10.3168/jds. 2016-12179

46. Stengärde L, Hultgren J, Tråvén M, Holtenius K, Emanuelson U. Risk factors for displaced abomasum or ketosis in Swedish dairy herds. Prev Vet Med. 2012;103(4):280-6. https://doi.org/10.1016/j.prevetmed.2011.09.005.

47. Gieseke D, Lambertz C, Gauly M. Relationship between herd size and measures of animal welfare on dairy cattle farms with freestall housing in Germany. J Dairy Sci. 2018;101(8):7397-411. https://doi.org/10.3168/jds.201714232.

48. European Commission. EU Milk Market Observatory [Internet]. EU. 2019. [cited 2019 Apr 13]. https://ec.europa.eu/info/food-farming-fisheries/ farming/facts-and-figures/markets/overviews/market-observatories/milk.

49. EARIB. Data enquiry. 2016. Available from: http://www.pria.ee.

50. Koeck A, Loker S, Miglior F, Kelton DF, Jamrozik J, Schenkel FS. Genetic relationships of clinical mastitis, cystic ovaries, and lameness with milk yield and somatic cell score in first-lactation Canadian Holsteins. J Dairy Sci. 2014; 97(9):5806-13. https://doi.org/10.3168/jds.2013-7785.

51. Strandberg E, Emanuelson U. Herd-level factors associated with longevity in Swedish dairy cattle. Acta Agric Scand A Anim Sci. 2016;66(2):92-8. https:// doi.org/10.1080/09064702.2016.1221986.

52. Lehmann JO, Fadel JG, Mogensen L, Kristensen T, Gaillard C, Kebreab E. Effect of calving interval and parity on milk yield per feeding day in Danish commercial dairy herds. J Dairy Sci. 2016;99(1):621-33. https://doi.org/10. 3168/jds.2015-9583.

53. Pryce JE, Coffey MP, Brotherstone S. The genetic relationship between calving interval, body condition score and linear type and management traits in registered Holsteins. J Dairy Sci. 2000;83(11):2664-71. https://doi. org/10.3168/jds.S0022-0302(00)75160-5.

54. Arbel R, Bigun Y, Ezra E, Sturman H, Hojman D. The effect of extended calving intervals in high-yielding lactating cows on milk production and profitability. J Dairy Sci. 2001;84(3):600-8. https://doi.org/10.3168/jds.S00220302(01)74513-4.

55. Allore HG, Erb HN. Simulated effects on dairy cattle health of extending the voluntary waiting period with recombinant bovine somatotropin. Prev Vet Med. 2000;46(1):29-50. https://doi.org/10.1016/S0167-5877(00)00137-9.

56. Bascom SS, Young AJ. A summary of the reasons why farmers cull cows. J Dairy Sci. 1998;81(8):2299-305. https://doi.org/10.3168/jds.S00220302(98)75810-2.

57. Pinedo PJ, De Vries A, Webb DW. Dynamics of culling risk with disposal codes reported by dairy herd improvement dairy herds. J Dairy Sci. 2010; 93(5):2250-61. https://doi.org/10.3168/jds.2009-2572. 
58. EUR-LEX R. no 1760/2000 of the european parliament and of the council of 17 July 2000 establishing a system for the identification and registration of bovine animals and regarding the labelling of beef and beef productsand repealing Council Regulation (EC) No820/97. 2000. https://eur-lex.europa.eu/ legalcontent/EN/LSU/?uri=celex:32000R1760.

59. Riigi Teataja. Animal disease control act. Riigi Teataja; 2014. p. 54. https://www.riigiteataja.ee/akt/128062014070.

60. Reimus K, Orro T, Emanuelson U, Viltrop A, Mõtus K. On-farm mortality and related risk factors in Estonian dairy cows. Prev Vet Med. 2018 Jul 1;155:53-60. https://doi.org/10.1016/j.prevetmed.2018.04.006.

61. Bradley A, Green M. Use and interpretation of somatic cell count data in dairy cows. In Pract. 2005;27(6):310-5. https://doi.org/10.1136/inpract.27.6.310.

62. Butler WR, Calaman JJ, Beam SW. Plasma and milk urea nitrogen inrelation to pregnancy rate in lactating dairy cattle. J Anim Sci. 1996;74(4):858-65. https://doi.org/10.2527/1996.744858x

63. Cain KC, Harlow SD, Little RJ, Nan B, Yosef M, Taffe JR, et al. Bias due to left truncation and left censoring in longitudinal studies of developmental and disease processes. Am J Epidemiol. 2011;173(9):1078-84. https://doi.org/10. 1093/aje/kwq481.

64. Dohoo IR, Martin SW, Stryhn H. Modelling Survival data. Vet Epidemiol Res. 2nd ed. Charlottetown: VER Inc.; 2009. p. 467-527.

\section{Publisher's Note}

Springer Nature remains neutral with regard to jurisdictional claims in published maps and institutional affiliations.

Ready to submit your research? Choose BMC and benefit from:

- fast, convenient online submission

- thorough peer review by experienced researchers in your field

- rapid publication on acceptance

- support for research data, including large and complex data types

- gold Open Access which fosters wider collaboration and increased citations

- maximum visibility for your research: over $100 \mathrm{M}$ website views per year

At $\mathrm{BMC}$, research is always in progress.

Learn more biomedcentral.com/submissions 